\title{
Potential influence of e-learning and Open Source solutions for education at Palacký University in Olomouc inspired by Polytechnic University in Valencia
}

\author{
Rostislav Nétek \\ Department of Geoinformatics, Palacký University in Olomouc, Czech Republic, \\ rostislav.netek@upol.cz
}

\begin{abstract}
This paper assesses different approaches in education between Western and Eastern Europe. It is based on a case study, comparing which compares universityies conventions inbetween Spain and Czech Republic, focusinged on e-learning and Open Source softwareources. The Eeducation system at Polytechnic University in Valencia (UPV) puts much more emphasis on open source solutions and elearning compared to the situation in Czech Republic. gvSIG is an open source geographic information system (GIS), co-developed at UPV as ain collaboration of commercial companies with research institutions. Lecturers at UPV significantly integrate free and open source (FOSS) into classes as well as they participate in open source communities like Planet gvSIG, gvSIG Outreach or Association for the promotion of FOSS4G and the development of gvSIG. In fact, a complex system for self-education in the field of GIS has been developed there. It combines positive relationship to open source solutions and takes advantage from all sections together. The "Aula Virtual" project is a virtual training classroom using the virtual educational platform. Great emphasis is put on step-by-step video tutorials. 300 videos are uploaded on PoliTube Channel, which contain both video and audio and "time-stamps-links". Time-stamp allows the possibility to switch among videos and other sources (annotation, webpages, etc.) dependent on the student's individual requirements. Compared to the situation in the Czech Republic, where proprietary software is still preferred in the academic sphere, this topic brings place for discussion. This paper discusses two different points of views, benefits of both of them and proposes a solution with regard to the specifics of Czech university education.
\end{abstract}

Keywords: E-learning, gvSIG

\section{Introduction}

In the last few years, free software became an alternative solution to proprietary software. The open source software is a phenomenon in all fields of information technology, moreover it is one of the most discussed topics, with significant impact in the field of Geoinformatics including both education and private sector, as well. Solutions based on open source are used every day nowadays for research, development and education, as well. The education of GIS is associated with the usage of e-learning platforms, which brings benefits for academic 
environments. A lot of ways for taking advantage of e-learning and for improving the teaching process, because solutions like video tutorials improve the effectiveness of learning. As [6] said "many GIS teachers select proprietary GIS software for education because students can learn the mainstream software skills and have advantages in the job markets". On the other hand, some GIS teachers prefer to use open source software because it is free of cost and allows the freedom to modify and distribute GIS applications.

\section{Motivation}

This paper summarizes different approaches in education between two universities in Western and Eastern Europe. It is based on a case study, comparing university conventions in Spain and Czech Republic. The author, originally from Czech Republic, spent two long-term internships at Polytechnic University in Valencia, where he met gvSIG for the first time and passed courses about it. He was surprised by the fact that in the Western Europe open source software was deeply implemented into education at universities compared to the situation in many universities in the Czech Republic.

\section{3. gvSIG}

gvSIG is an open source Geographic Information System (GIS). The development with the aim to replace proprietary GIS software is funded by the regional government of Valencia (Spain). The abbreviation gvSIG means Generalitat Valenciana Sistema d'Informació Geogràfica. Government of Valencia community wrote down in 2003 some requirements for development new GIS application: portability, modularity, open-source license, interoperability, support of several standards. The development has been realized by a compact group of private companies and research institutions including universities, so a number of scientific extensions for GIS analysis are currently being built. It runs on Windows, Linux, and Mac OS X operating systems under the GNU General Public License (GPL), which allows free use, distribution, study and improvement. It supports many OGC/ISO standards for geospatial data and due to modularity it should be extensible by additional extensions. Currently gvSIG is available in 13 languages [2], [11].

In general gvSIG is a complex platform, besides desktop basement there are other components. According to [11] "gvSIG Desktop is a powerful GIS solution designed to offer a free solution to all needs related to geographic information management. It is characterized as a comprehensive, easy to use solution, adapted to the user's needs". According to [12] gvSIG Mobile is characterized as "a project aimed to develop a free and open source GIS/SDI client on mobile devices. gvSIG Mobile is a version of gvSIG Desktop adapted for mobile devices, with support for shapefiles, GPX, KML, GML, ECW, WMS and images, capable of using GPS. Moreover, there is an extension for gvSIG Desktop, which enables to export geographical data from gvSIG Desktop to gvSIG Mobile". Moreover, gvSIG Mini is available for a mobile phones and provides the possibility to display map service atntiles, as OpenStreetMap, Yahoo Maps, Microsoft Bing and others on the platform of smartphones and mobile devices. Itis available as gvSIG Mini for Android and gvSIG Mini for Java [11].

According to [8] QGIS and gvSIG are widely widespread for education reasons on european universities (see Figure 1). According to [3] research testing gvSIG and QGIS appear to be relatively more suitable than the others. The disadvantage of gvSIG, is that the starting 
up time is longer than others, but in fact, time about 10 seconds are adequate. Moreover, according to [3] testing gvSIG offered balanced performance in efficiencies and functionalities at an acceptable level and was recommended for their research. According to another research made by [5] gvSIG was the second best GIS software with 106 functions in total, while the first position occupies commercial product ArcGIS.

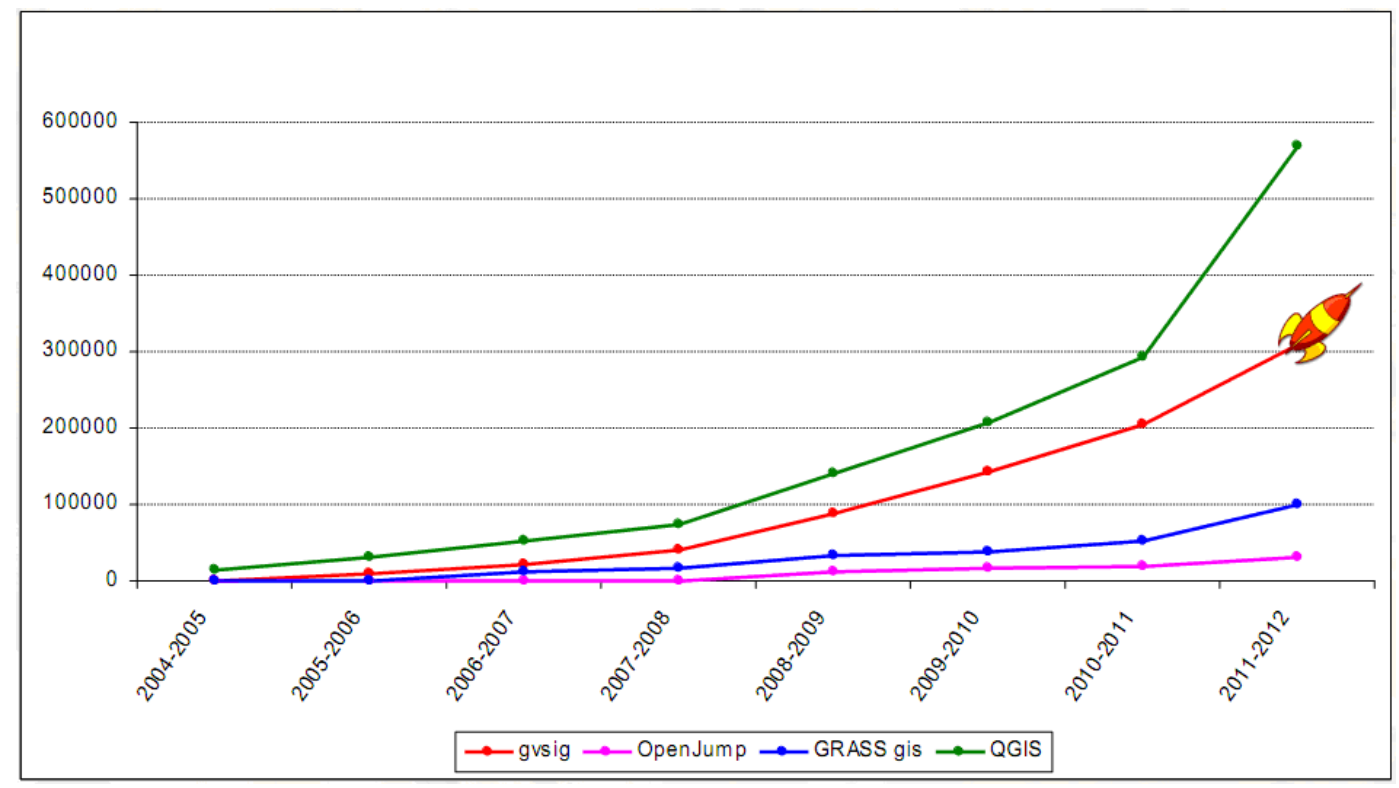

Figure 1: Distribution of main open source software; source: Vázquez 2011.

\section{Approach at Polytechnic University in Valencia, Spain}

\subsection{Attitude to open source}

There is an elegant example, how Spain education reacts on the typical argument about open source. Some years ago, they write down two stereotypes about free software: 1) it is not quality software and 2) companies do not support free software [1]. These stereotypes were clarified and explained into the positive meaning, due to progressive approach in the education system . Currently Spanish lecturers argue with these two answers: 1) "Good software and bad software can be found in free platform as well as in commercial products. The advantage is that in the case of free software the quality can be detected and adjusted according to the user's needs, due to its open and free nature." 2) "It is a lie - there are many companies supported free software but with a different type of business model. It is based on offering professional services where all of the investments are allocated towards generating wealth; not in a model where selling the product is the main component of the business thereby converting part of investment into an expense" [1]. Opposed to other countries in Europe, this approach is fully accepted for Spain education in the field of Geoinformatics. It means that free and commercial software has the same importance and none of them is preferred significantly due higher GI education (typically bachelor study), when students gain a general knowledge about GIS solutions. In fact, the Spanish argument is that both commercial and free software stay on the same start-line, no one is preferred, because it is extremely important to be familiarize with both kinds of way during education period. 


\section{2. gvSIG project at UPV}

According to real experiences, education at UPV shows typical approach how implement open source solutions into higher education successfully. atnAcademic teachers at UPV have enormous enthusiastic for gvSIG project, because UPV collaborates on gvSIG development by Research Group of Geoenvironmental Mapping atnand Remote Sensing (CGATatn). The reason is clear, due to many connections to Valencia district,atn atnthe UPV is just in the centre of the gvSIG development since the beginning. On the other side, UPV participate on the project by the course which is focused on gvSIG, some research projects with focus on gvSIG were made there, educational web blog about gvSIG is written by the lecturer; the whole package of video tutorials was made for students, an international gvSIG conference takes place in Valencia every year and many more.

The main focus of activities is put on the gvSIG course. Strong emphasis is put on elearning and self-education beside common teaching, there is a full semester project based on collaborative team working, when only task is done. Usually the task is following from real necessities, real data are used, and outputs are sometimes used in practice by companies (specific logistic problem, evidence of children parks, etc.). No demo data or theoretical silly tasks. The process of working and results are fully under the students' direction, which is quite innovative method compared to the previous situation at Palacký University, Czech Republic. Just this approach was the inspiration for implementing similar lesson at Palacký University. In summary, the positive attitude and enthusiastic from teachers is the cornerstone for implementing open source into the education.

\subsection{Aula Virtual \& Video tutorials}

For every need students can use excellent source - complex interactive tutorial. It was made by CGAT especially for UPV student courses and it is divided into four parts. The first one is a general introduction into GIS; the second one is focused on the geospatial data and theirsources in Spain (e.g. IDEE, INSPIRE). The core part is the complete manual - it describes all ways how to work with gvSIG programme: the installation, the interface, all functions and extensions as well as specialized case [7]. The teaching is quite intuitive, becauese this part is described in every detail, every step is added by images and in every chapter examples and some exercises are write-down. The last part is the complete video tutorial where each of discussed step and examples are recorded. This is the best way for e-learning. In this type of study, there is no space for constrains or student questions. Moreover, this complex tutorial is supplemented by another source written by the lecturer. Some exercises and questions on gvSIG are discussed on education web blog [10]. In comparison to tutorial, this source describes details and new features related to university education.

The "Aula Virtual" project is a virtual training classroom, which takes place in gvSIG under the agreement between the Department of Infrastructure and Transport of Generalitat Valencia and the Polytechnic University of Madrid. The aim of the project is to develop and implement virtual classroom for gvSIG training programme, using the virtual educational platform called MOODLE. The results of this project are available for users all over the world with a focus on gvSIG teaching and learning through e-learning process. This component involves a series of activities, covering intermediate and advanced level [4]. The courses include a number of activities like practices, exercises or quizzes based on interactive commu- 


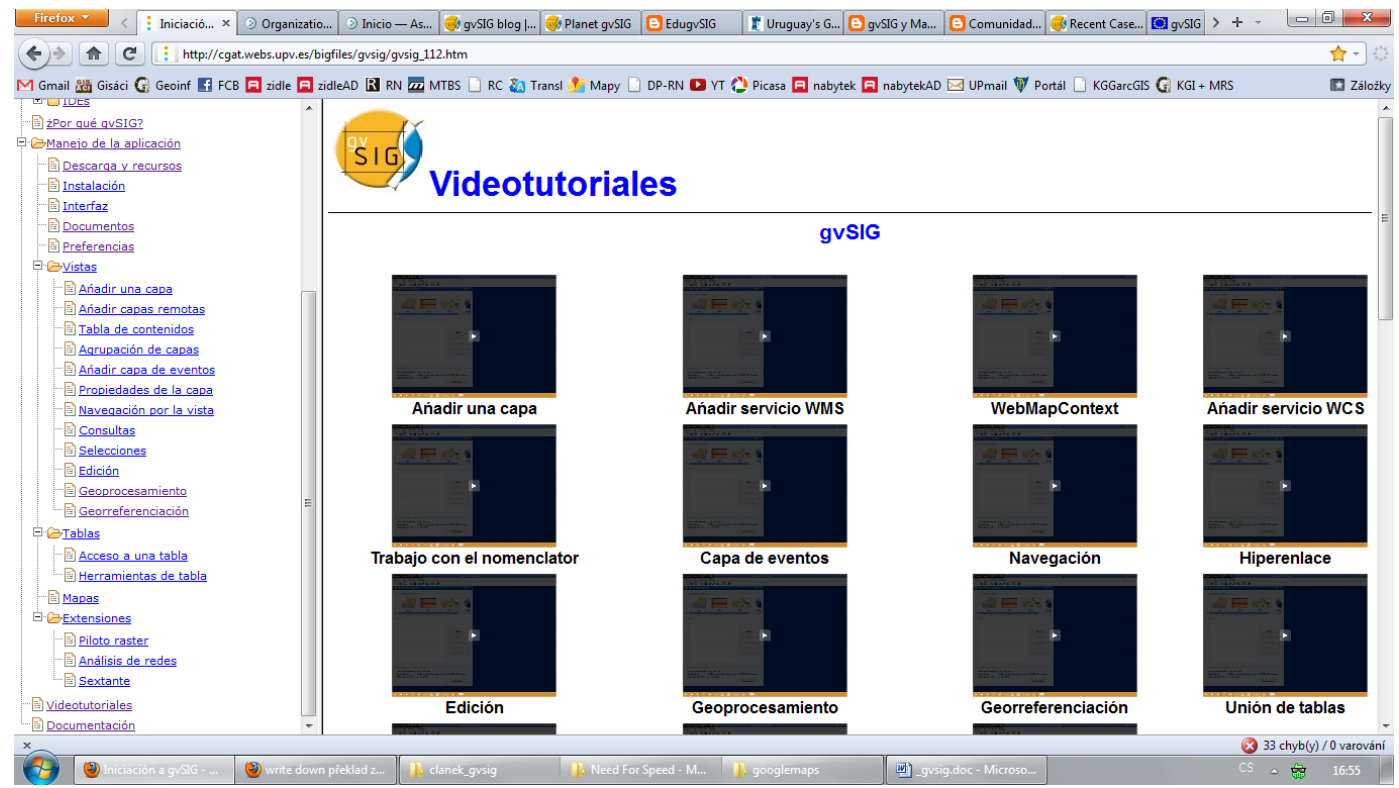

Figure 2: Video tutorial as part of complex interactive education source made by CGAT.

nication, including hypertext, images, videos and audio files. It means that conventional teaching approach is fully supported by innovative e-learning methods, like video files or virtual classroom.

\subsection{Spanish Spatial Data Infrastructure \& Web Services}

Finally, another advantage for Spanish education in the field of Geoinformatics, is the fact that all data produced in area of Spain are available on Spanish Spatial Data Infrastructure (IDEE). The main goal is to integrate through the Internet all data, metadata, services and geographic information in Spain, within the State, Regional and Local government level. IDEE provides more than 1000 WMS and 200 WFS sources. In fact, IDEE is considered as complete data source by common users, it is fully supported by all Spain society and the system really works. Due to this fact Web Services are widely used by users, including universities [13].

\section{Approach at Palacký University in Olomouc, Czech Republic}

Compared to the situation in the Western Europe, there is quite different point of view at Palacký University. According to the current syllabus [9] at Department of Geoinformatics during bachelor study students meet ArGIS software in eight courses, while there is only one free software course. It describes unbalance of propagation free software, despite the advantages. Typically commercial software ArcGIS by Esri is preferred more than others for GIS education at all Czech universities. On the other side, nowadays there is increasing number of teachers and new courses focused on open source and e-learning systems are used widely. Find the reasons is a hard question, probably it is caused by quite different habits, behaviour and history. Generally said, the education training is based more on theoretical point of view and individual approach, compared to collaborate working in the Spain. On the 
other side, according to real experiences from students' internships, Czech students sometimes have better disposition for the beginning working in the companies after they graduate.

\subsection{Open source course}

Inspired by the situation at the UPV, there is an effort widely implement open source into education at the Department of Geoinformatics, UPOL. As a pilot case was chosen course "Programmatic tools of GIS 2" in the summer semester 2012. The course visited 31 students in total; they were divided in groups of 4-5 persons. The course introduces general requirements of the open source approach and softwares such a SAGA GIS, QGIS and GRASS are mentioned. Most of the time and interest is given on gvSIG project and it is divided into two separate parts. During lessons every week the basic steps are shown practically in the classroom, for every lesson new homework is assigned. Based on the fact, that most of the homeworks or projects were solved individually, this course is oriented for collaborate process, students work together in teams. Moreover, the strong emphasis is put on self education in groups through digital sources, which is quite innovative method there. The task and sources are done, in fact, the whole process of searching for the materials, working and result presentations is fully under the student's direction. The teacher checks all steps, he gives advice and answer to the question, but the students are responsible for the management of problem solving. For group exercises focused on gvSIG, complex structure of education material was summarized, which contains two main parts: video tutorials made by CGAT (section 5.2) and list of e-learning sources focused on gvSIG (section 5.3). At the end of course voluntary evaluation was made by questionnaire. The students describe their feelings about collaborative working there. Generally, the course brings benefits of independent and project management experiences, but lots of them criticize number of team members. Five people for each team is quite enough for collaborate working on GIS project made on one laptop.

\subsection{Video tutorials}

For self education was chosen complex system made by CGAT as a primary source (see section 4.3). It describes working with gvSIG programme step by step, divided into four levels. First level contains only plain text about the task a solution, in the second one is captured screen supplemented by labels, which is an appropriate solution in many similar sources. In the next level "static" tutorial is replaced by video tutorial with audio description. More than 300 videos are uploaded on both YouTube Channel and PoliTube Channel. Moreover videos contain "timestamps" connected with annotation and "links" provide connection with timestamp into another video. In fact, all videos make a network structure and there is possibility to switch among videos dependent on user's needs. The last level contains links to another source like tutorials, manuals, on-line courses, forums or web blogs of gvSIG community (see section 5.3). This complex system brings benefits that students can learn any step anytime, anywhere and no matter how often they repeat it.

\section{3. gvSIG community}

Generally, free software has one or two official web pages with some forum where users' questions are answered. The situation about gvSIG project is quite different. Spanish and English speaking users can find a huge number of online sources, like official pages about 


\section{Canal EdugvSIG. Mejoras en los videotutoriales}

Respecto de la estructura

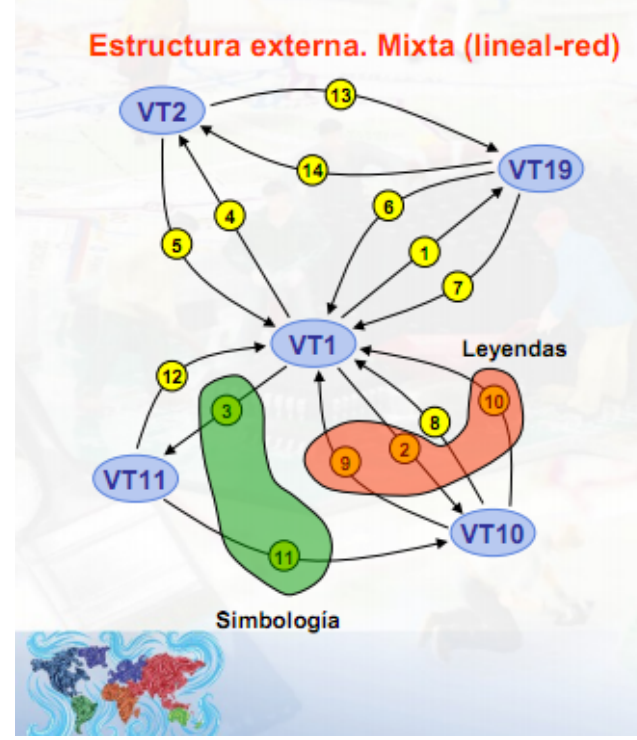

(1) Añadir capa raster (VT19; 0m:09s)

(2) Trabajar con leyendas (VT10;0m:14s)

(3) Simbologia avanzada (VT11; 0m:10s)

(4) Añadir capa WMS (VT2; $1 \mathrm{~m}: 0.3 \mathrm{~s})$

(5) Añadir capa vectorial (VT1; $1 \mathrm{~m}: 57 \mathrm{~s})$

(6) Añadir capa vectorial (VT1; $1 \mathrm{~m}: 57 \mathrm{~s})$

(7) Propiedades capa vectorial (VT1; $2 \mathrm{~m}: 02 \mathrm{~s})$

(8) Acceso a propiedades de capa (VT1; 2m:02s)

(9) Leyenda por símbolo único (VT1; 4m:09s)

(10) Leyenda por valores únicos (VT1; $2 \mathrm{~m}: 02 \mathrm{~s})$

(11) Simbologia lineal por capas (VT10; 4m:29s)

(12) Uso del localizador (VT1; 3m:05s)

(13) Añadir capa raster (VT19; 0m:09s)

(14) Añadir capa WMS (VT2; $1 \mathrm{~m}: 0.3 \mathrm{~s})$

1 औ1

Figure 3: Network structure of video tutorials by CGAT; timestamps and links provide connections between videos; source: Vázquez 2011.

gvSIG project, forums and blogs as well as unofficial fan pages. On the other side, there is a disproportion between digital sources and published paper books. gvSIG is a pure example of open source programme developed by collaborate process by people which are seriously interested in. Their aim is to develop powerful software, which is obtained with communication. This communication takes place on the Internet only, because of fast feedback compared to conventional process. In fact, at the same date, when the book is published, the book is not actual. The rapid evolution in the digital media brings changes every day. That is the reason, why gvSIG is supported by many web sources first of all (similarly to another open source projects). Following list shows some selected examples of digital sources focused on gvSIG, which are used by students for education at UPOL.

http://www.gvsig.gva.es/ - The official web page

http://www.gvisig.org/ - The official international web page

http://gvsig.com/ - The official web page of gvSIG association

http://blog.gvsig.org/ - The web blog of gvSIG project team

http://planet.gvsig.org/ - The community of bloggers

http://gvsigce.org/ - The gvSIG community edition

http://outreach.gvisig.org/case-studies - Another community

http://edugvig.blogspot.com/ - The web blog focused on education with gvSIG

http://gvigmac.blogspot.com/ - The web blog focused on gvSIG solution on Macintosh platform http://www.gvsig-training.com/ - Training platform of gvSIG association

http://gvsig3d.blogspot.com/ - The web blog focused on 3D visualization by gvSIG

http://gvigig-argentina.blogspot.com/ - The web blog focused on usage gvSIG in South America http://gvsigrussia.wordpress.com/ - The web blog focused on usage gvSIG in Russia 


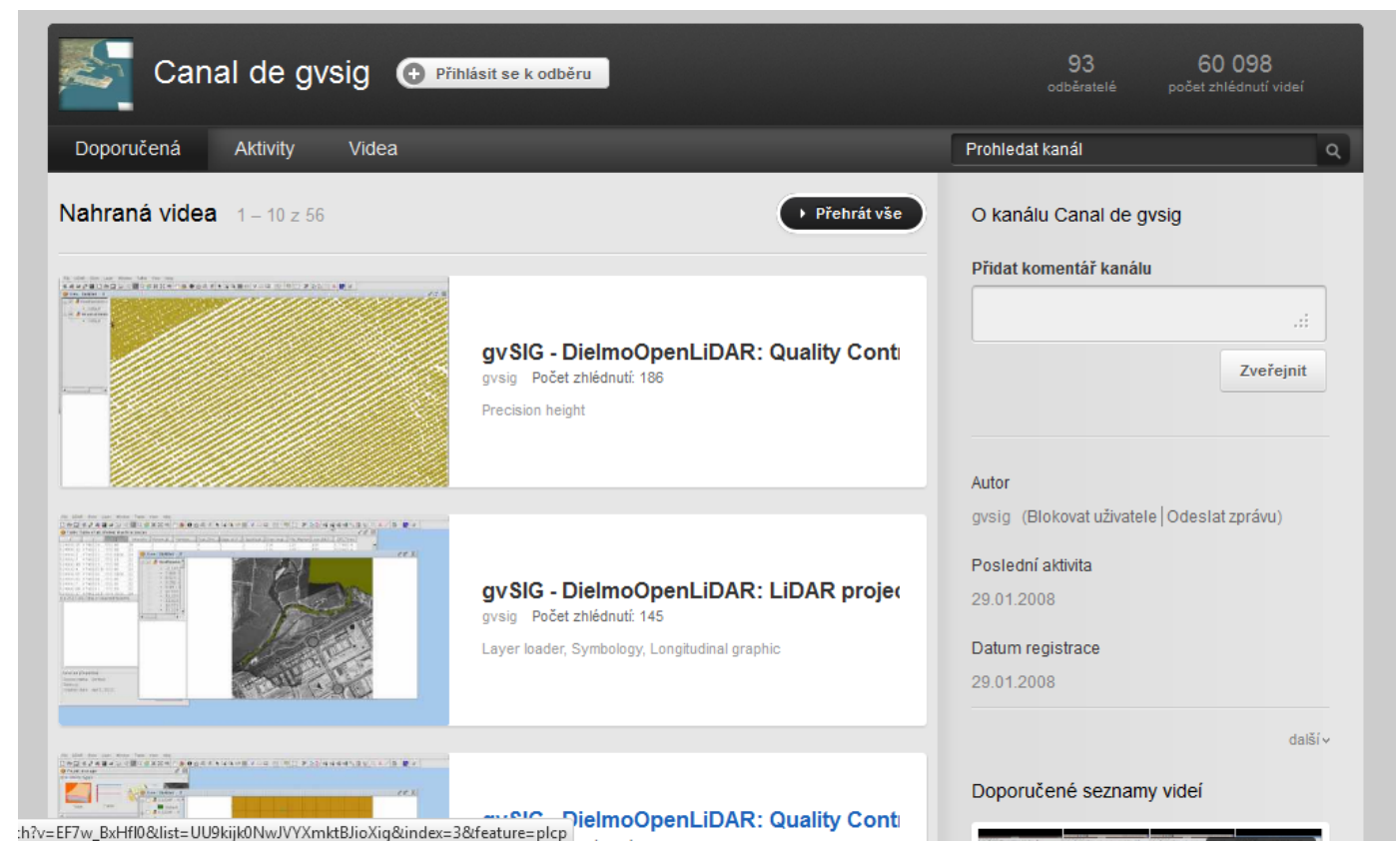

Figure 4: YouTube Channel of gvSIG project.

https://joinup.ec.europa.eu/software/gvsig-desktop/description - The gvSIG overview http://mmedia.uv.es/index?way=visited\&f=tc. category_id\&w=212 - Aula Virtual Multimedia http://cartolab.udc.es/cartoweb/fonsagua/ - The Water and sanitation programs on gvSIG http://cartolab.udc.es/cartoweb/gvsig-eiel/ - The Survey of Local Infrastructure and Equipment

http://foss4gis.blogspot.com/ - Another web blog about gvSIG

http://gvsigconsultoresaa.blogspot.com/ - Another web blog about gvSIG

http://jornadas.gvsig.org/ - International conference about gvSIG

http://cgat.webs.upv.es/bigfiles/gvsig/gvsig_112.htm - Interactive course made by CGAT

Beside the core software, official community was established. The objective of the "Association for the promotion of FOSS4G and the development of gvSIG",also called gvSIG Association, is the sustainability of the gvSIG project based on the maintaining of the professional structure and the infrastructures of the gvSIG Community.

The gvSIG Association operates gvSIG training webpage which offers training and learning courses for single users, developers and organizations, as well. A lot of courses, are available for free as well as paid workshops and webinars.

Planet gvSIG is a main gateway of websites made by gvSIG community members

The gvSIG Campus Community: This group of community emerges as a result of the work done mainly by the universities on projects. This new stage focuses on expanding this working group, promoting the participation of universities and tertiary training institutions in different countries and different areas (e.g. geomatics) having interest to undertake student's work related to gvSIG products.

The gvSIG blog is oriented on practical examples and exercises with programs, solving the errors and bugs. 
On the gvSIG Outreach students can find real case studies where gvSIG solution is applied into the practice.

Last but not least source should be a list of contributors, who write personal blogs or articles about gvSIG (Figure 5).

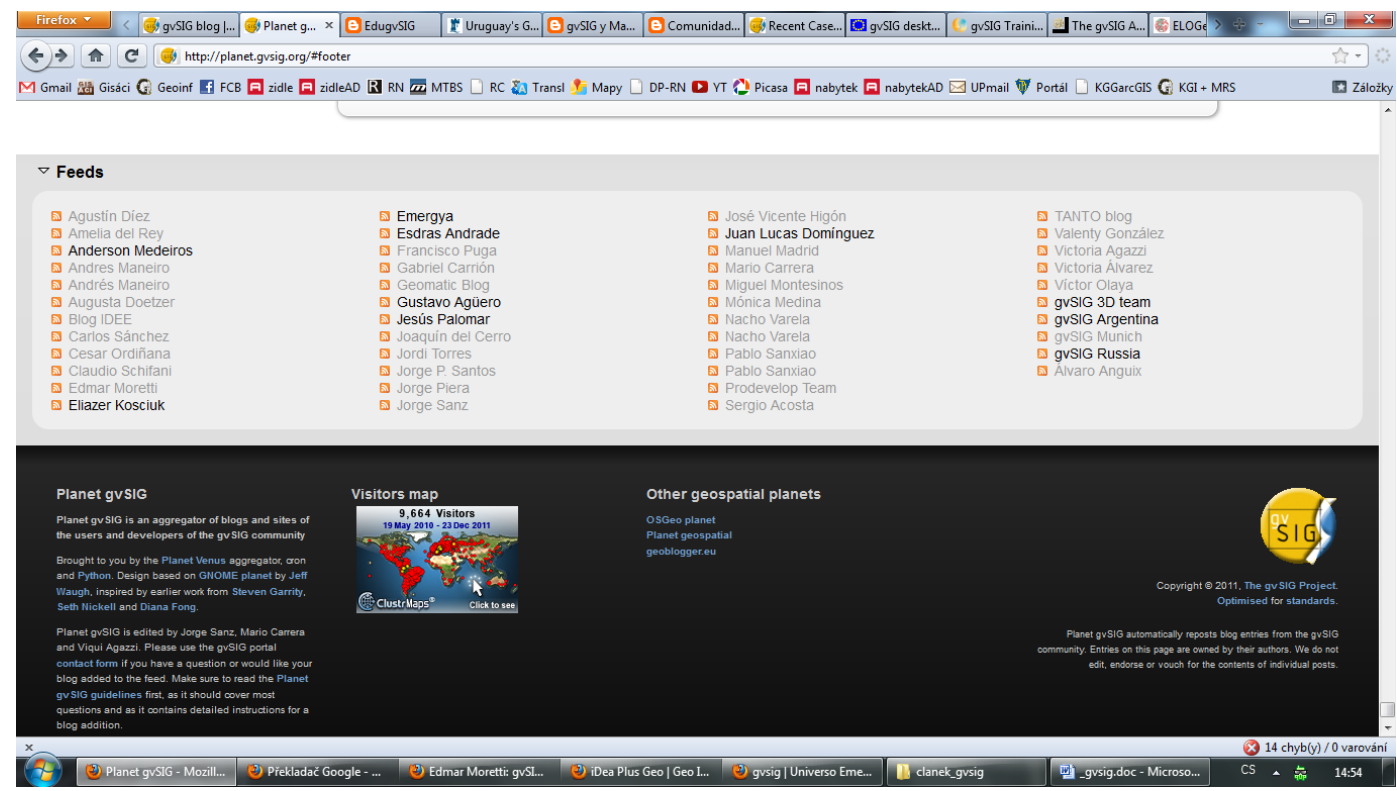

Figure 5: List of contributors on Planet gvSIG.

\section{Conclusion}

The purpose of this paper is to show different approaches in using open source for education between Polytechnic University in Valencia (Spain) and Palacký University in Olomouc (Czech Republic) and to give an overview how open source solution should be implemented into the education. Although commercial software played dominant role for GIS development in the past, the open source solutions has become a stronger influence in the last years. There is no technical reason why commercial software should be preferred so significantly, because each alternative programme (e.g. gvSIG) provides the same basic features, functions and analysis as proprietary software. Moreover, the open source brings benefits like interoperability, open source code, free cost, etc. The phenomenon of free software is obvious at Spanish universities first of all. Positive approach to open source by Spanish academician should be described by three main characteristics:

1. Neither commercial nor free software is preferred or repressed.

2. Positive attitude and enthusiastic for FOSS by academics.

3. E-learning supports conventional teaching process.

Based on the experiences from Polytechnic University in Valencia, there is the range of learning possibilities, which should be implemented to support new learning environment. The current syllabus at Palacký University demonstrates that ArcGIS software is used in eight courses, while open source in only one. A pilot course "Programmatic tools of GIS 2" in the 
summer semester 2012 has been opened. It has been oriented on open source solutions only, especially on gvSIG project. Number of 31 students in total have been registered in. For collaborate requirements they were divided in groups of 4-5 persons. The education structure is patterned on self education in students' teams, in combination of e-learning sources. Interactive tutorial based on videos and list of web sources have been prepared for every lesson by the lecturer. This is an innovative process of education there. According to student's evaluation this structure is more comfortable for them due to possibility repeating sources and co-working anytime and anywhere, but it is crucial to be in the connection with lecturer. Strong recommendation is to check students' steps by lecturer every week and ask them if any assistance is required. Each group should apply different steps, due to the fact that learning process is fully managed by students, but lecturer's role is to keep the steps in the right direction by well-timed tips and helps. Individual habits between Czech and Spain academic system require a different number of team-members. Students confirmed that communication in the group of five students is complicated in case of computer-based exercises. About three or four persons should be set as ideal number of members for incident-free collaborate working.

As has been emphasised, this case study can provide opposite of courses where only proprietary software is used. Using GIS open source classes has been proven as highly eligible for bachelor study, because students gain an alternative overview. The main recommendation is to enable students be familiarize themselves with both types of software. No matter which free software is introduced, but general principles and advantages of FOSS are crucial for students' overview. The benefit of described course is that some students themselves have expressed interest for open source topic for its bachelor thesis, which was not regular before. General recommendation for the following course is to be focused on one software only, because of similar interface and operating. If free software is used, the sources of free data should be mentioned, as well. From the practical point of view, it is strongly recommended to present law and legal issues of FOSS as well as the possibility of customization and extension by open source code. The open source course was positively evaluated by all students as well as by the lecturer. Based on experiences from the first round, the same course will continue in the summer semester 2012/2013.

\section{References}

[1] ANGUIX A. (2011): $7^{\text {th }}$ International gvSIG conference. Valencia, $92 \mathrm{p}$.

[2] CROPPER, S. (2010): The use of gvSIG as the primary geographic information system for the analysis of spatial data and the production of maps in a small ecological consulting firm. In: Open Planet, Vol. 4, pp. 20-29.

[3] CHEN, D. et al. (2010): Assessment of open source GIS software for water resources management in developing countries. In: Journal of Hydro-environment Research, Vol.4, pp 253-264.

[4] POVEDA M. A. B., GONZALES, M. A. (2010): Proyecto: Aula Virtual gvSIG. Madrid, $8 \mathrm{p}$. 
[5] SILLERO N., TARROSO P. (2010): Free GIS for herpetologists: free data sources on Internet and comparison analysis of proprietary and free/open source software. In: Acta Herpetologica, Vol. 5, pp 63-85.

[6] TSOU M., SMITH J. (2011): Free and Open Source Software for GIS education. San Diego, $18 \mathrm{p}$.

[7] URBANO, F. et. al. (2010): Wildlife tracking data management: a new vision. In: Philosophical transaction of the Royal Society, Vol. 365, pp 2177-2185.

[8] VÁZQUEZ, J.P., PLATERO, M.M.N. (2011): ¿Cúal es la mejor forma de aprender gvSIG? In: $7^{\text {th }}$ International gvSIG conference, Valencia, $40 \mathrm{p}$.

[9] Courses - bachelor study Geoinformatics. Online [http://geoinformatics.upol.cz/ epredmety $\cdot$ php]

[10] EdugvSIG. Online [http://edugvsig.blogspot.com/].

[11] gvSIG Desktop. Online [http://www.gvsig.com/products/gvsig-desktop].

[12] gvSIG Mobile. Online [http://www.gvsig.com/products/gvsig-mobile?set_ language $=\mathrm{en}]$.

[13] IDEE. Online [http://www.idee.es/showNewsList.do?cid=pideep_noticias]. 
